\title{
Complement factor H-related 3 overexpression affects hepatocellular carcinoma proliferation and apoptosis
}

\author{
HONG LIU ${ }^{1 *}$, LIGANG ZHANG $^{1 *}$ and PENGYAN WANG ${ }^{2}$ \\ Departments of ${ }^{1}$ Hepatology, and ${ }^{2}$ Research and Education, \\ Yantai Infectious Disease Hospital, Yantai, Shandong 264001, P.R. China
}

Received May 11, 2018; Accepted December 7, 2018

DOI: $10.3892 / \mathrm{mmr} .2019 .10514$

\begin{abstract}
Complement factor H-related 3 (CFHR3) belongs to the human factor $\mathrm{H}$ protein family and is associated with various human diseases, including nephropathy, age-related macular degeneration and atypical hemolytic uremic syndrome. However, to the best of our knowledge, the role of CFHR3 in hepatocellular carcinoma (HCC) remains largely unknown. In the present study, reverse transcription-quantitative polymerase chain reaction (RT-qPCR) and western blot analysis were performed to determine mRNA and protein expression levels of CFHR3 in HCC and normal adjacent tissue. In addition, CFHR3 was overexpressed in Huh-7 cells and cell counting kit- 8 assay was used to determine cell viability. Cell proliferation and apoptosis were assessed using flow cytometry, RT-qPCR and western blotting. The results demonstrated that mRNA $\left(2^{-\Delta \Delta \mathrm{Cq}}\right)$ and protein expression levels of CFHR3 were significantly lower in tumor tissue compared with in adjacent tissue. Additionally, CFHR3 overexpression decreased cell viability, inhibited cell proliferation and significantly increased apoptosis. It was also identified that CFHR3 could downregulate the expression of Ki67. The results suggested that CFHR3 induced apoptosis by downregulating the expression of survivin and B cell lymphoma 2, upregulating the expression of Bcl-2-associated $\mathrm{X}$ and promoting caspase- 3 activity. Western blotting revealed that CFHR3 significantly inhibited the protein expression levels of phosphorylated (p)-phosphoinositide 3-kinase (PI3K), p-protein kinase B (Akt) and $\mathrm{p}$-mammalian target of rapamycin (mTOR). Overexpression of CFHR3 suppressed proliferation and promoted apoptosis of HCC cells by inhibiting the PI3K/Akt/mTOR signaling pathway.
\end{abstract}

Correspondence to: Dr Ligang Zhang, Department of Hepatology, Yantai Infectious Disease Hospital, 62 Huanshan Road, Yantai, Shandong 264001, P.R. China

E-mail: ligangz_zhang@163.com

*Contributed equally

Key words: CFHR3, HCC, apoptosis, proliferation, PI3K/Akt/ mTOR

\section{Introduction}

Liver cancer is one of the commonest types of cancer, with $\sim 850,000$ new cases being diagnosed annually worldwide (1). Hepatocellular carcinoma ( $\mathrm{HCC}$ ) is the most common type of primary liver cancer and accounts for $\sim 90 \%$ of all liver cancer cases (2). HCC is the second leading cause of cancer related mortality in China (3). The high rate of mortality could be explained by many risk factors, including hepatitis $\mathrm{B}$ and $\mathrm{C}$ virus infections as well as excessive alcohol intake and chronic liver injury, all of which can contribute to the development of HCC (4-6). A previous study demonstrated that complement factor H-related (CFHR) 3 is highly expressed in normal liver tissue, but not in other tissues (7). This tissue-specific expression led to the hypothesis that CFHR3 may serve a role in HCC.

CFHR3 belongs to the human factor $\mathrm{H}$ protein family, which contains complement regulators, including complement factor $\mathrm{H}(\mathrm{CFH})$ and $\mathrm{CFH}$-like protein 1 as well as other CFHR proteins (8). CFH family proteins have individual folding domains that are called short consensus repeats. These are also reflected in the tandem arrangement of the $\mathrm{CFH}$ gene and the five CFHR genes. Notably, CFHR3 and CFHR4 are similar, and have overlapping functions (9-11). Previous studies have reported that $\mathrm{CFH}$ genes are associated with several human diseases, including age-related macular degeneration, atypical hemolytic uremic syndrome and membranoproliferative glomerulonephritis type II (12-15). These diseases are increasingly thought to be caused by $\mathrm{CFH}$ polymorphisms, homozygous or heterozygous mutations and CFHR1/3 deletion (16-18).

Using in-situ hybridization, it was revealed that many tumor cells, including bladder, cervical and renal cancer cell lines, can produce and secrete human CFHR proteins $(19,20)$. However, normal epithelial keratinocytes and colon cancer cell lines do not express CFHR proteins (21) . Several studies have suggested that tumor cells evade the immune system by using CFH and its associated proteins (22-24). Cui et al (25), suggested that abnormal expression of the CFHR1 and CFHR3 gene may be related to cisplatin resistance in $\mathrm{U} 251 / \mathrm{CP} 2$ gliomas. However, to the best of the authors' knowledge, no studies have been conducted on the relationship between CFHR3 expression and HCC.

The phosphoinositide 3-kinase/protein kinase B/mammalian target of rapamycin (PI3K/Akt/mTOR) pathway is known 
to be regulated in HCC (26). Thus, in the present study, the aim was to determine whether CFHR3 could inhibit liver cancer cells via the PI3K/Akt/mTOR pathway.

\section{Materials and methods}

Patients and tissue. Between May 2005 and July 2017, 42 HCC and adjacent normal tissues samples were collected from patients with HCC (age: 55.1 \pm 9.2 years; 23 male, 19 female), undergoing surgical resection at the Yantai Infectious Disease Hospital (Yantai, China). Inclusion criteria were HCC diagnosed according to Clinical diagnosis and staging of Primary Hepatocellular carcinoma (27). Exclusion criteria were patients receiving hormones and/or antineoplastic drugs, radiotherapy or chemotherapy within 2 weeks prior to surgery. Tissues were confirmed as HCC following pathological examination. The normal liver tissues were taken at a distance of $>2 \mathrm{~cm}$ from the edge of the tumor. All HCC specimens and corresponding adjacent normal tissues were collected within $0.5 \mathrm{~h}$ of surgical resection. One section of the paired tissues was used for pathological diagnosis and stored in $4 \%$ formaldehyde, while the section was stored in liquid nitrogen for later experimentation. This study was approved by the Ethics Committee of Yantai Infectious Disease Hospital (Yantai, China). Written informed consent was obtained from the patients.

The Cancer Genome Atlas (TCGA) database. Another cohort of patients with HCC was obtained from the TCGAdatabase (https://cancergenome.nih.gov/) via the Genomic Data Commons Data Portal. The expression values of genes from RNA-seq data were scaled with $\log 2($ FPKM +0.01$)$. The CFHR3 expression in human tissues. Using NCBI database (https://www.ncbi.nlm.nih.gov/gene/10878), RNA-seq was performed on tissue samples from 95 human individuals representing 27 different tissues in order to determine tissue-specificity of all protein-coding genes.

Cell culture. The Huh-7 cell line was purchased from Procell Life Science \& Technology Co., Ltd., (Wuhan, China). Cells were cultured in RPMI 1640 medium (HyClone; GE Healthcare Life Sciences, Logan, UT, USA) containing 20\% fetal bovine serum (FBS; Gibco; Thermo Fisher Scientific, Inc., Waltham, MA, USA) at $37^{\circ} \mathrm{C}$ and $5 \% \mathrm{CO}_{2}$. The cells were digested with $0.25 \%$ trypsin (Gibco; Thermo Fisher Scientific, Inc.) and passaged when cells reached 80-90\% confluence.

Cell transfection. CFHR 3 overexpression and negative control (NC) plasmids were purchased from Shanghai GenePharma Co., Ltd. (Shanghai, China). Cells were seeded in 6-well plates $\left(3 \times 10^{5}\right.$ cells/well) one day in RPMI 1640 medium before transfection. Transient transfection was carried out using Lipofectamine $^{\circledR} 3000$ (Invitrogen; Thermo Fisher Scientific, Inc.), according to the manufacturer's protocol. Cells were transfected with $20 \mu \mathrm{M}$ CFHR3 overexpression or NC plasmids using $5 \mu 1$ Lipofectamine ${ }^{\circledR} 3000$, in serum-free medium at $25^{\circ} \mathrm{C}$ for $10 \mathrm{~min}$. Cells treated with $0.1 \%$ PBS were used as the control. Following a $6 \mathrm{~h}$ incubation at $37^{\circ} \mathrm{C}$, the cells were cultured in RPMI 1640 medium containing 10\% FBS. Cells were used for subsequent experiments 3 day later.
Reverse transcription-quantitative polymerase chain reaction $(R T-q P C R)$. RT-qPCR was performed to examine the gene expression levels of CFHR3, Ki67, survivin, caspase-3, Bcl-2-associated X (Bax), B cell lymphoma 2 (Bcl-2), PI3K, Akt and mTOR. Total RNA was extracted from tissues samples or cultured cells using TRIzol ${ }^{\circledR}$ (Invitrogen; Thermo Fisher Scientific, Inc.), according to manufacturer's instructions and reversed transcribed to cDNA using the QuantiTect Reverse Transcription kit (Qiagen GmbH, Hilden, Germany). The RT conditions were as follows: $37^{\circ} \mathrm{C}$ for $60 \mathrm{~min}$ and $95^{\circ} \mathrm{C}$ for 5 min. qPCR was carried out using the SYBR qPCR Mix (Toyobo Life Science, Osaka, Japan), with GAPDH as the internal reference. The thermocycling conditions were as follows: $95^{\circ} \mathrm{C}$ for $10 \mathrm{~min}$, followed by 40 cycles of $95^{\circ} \mathrm{C}$ for $10 \mathrm{sec}, 60^{\circ} \mathrm{C}$ for $10 \mathrm{sec}$ and $72^{\circ} \mathrm{C}$ for $10 \mathrm{sec}$. The primer sequences are listed in Table I. The relative mRNA expression levels were calculated using the $2^{-\Delta \Delta \mathrm{Cq}}$ method (28).

Western blotting. Total protein was extracted from tissues or cultured cells using lysis RIPA buffer (Thermo Fisher Scientific, Inc.), followed by centrifugation at $18,000 \mathrm{x}$ g for $5 \mathrm{~min}$ at $4^{\circ} \mathrm{C}$. Protein concentration was determined using an Enhanced BCA Protein Assay kit (Beyotime Institute of Biotechnology, Shanghai, China). Proteins ( $20 \mu \mathrm{g} / \mathrm{lane})$ were separated by $10 \%$ SDS-PAGE and transferred onto polyvinylidene difluoride membranes, which were blocked with 5\% milk in Tris-buffered saline containing $0.2 \%$ Tween-20 (TBST) at room temperature for $2 \mathrm{~h}$. Proteins were incubated with primary antibodies: Rabbit anti-CFHR3 (1:1,000; cat. no. 16583-1-AP; ProteinTech Group, Inc., Chicago, IL, USA), rabbit anti-Bcl-2 (1:1,000; cat. no. ab32124; Abcam, Cambridge, MA, USA), rabbit anti-Bax (1:1,000; cat. no. ab32503; Abcam), rabbit anti-Ki67 antibody (1:1,000; cat. no. ab16667; Abcam), rabbit anti-survivin (1:5,000; cat. no. ab76424; Abcam), rabbit anti-caspase-3 (1:500; cat. no. ab13847; Abcam), rabbit anti-PI3K antibody (1:500; cat. no. orb137259; Wuhan Booute Co. Ltd., Wuhan, China), rabbit anti-p-PI3K antibody (1:1,000; cat. no. 4228; Cell Signaling Technology, Inc., Danvers, MA, USA), rabbit anti-pan-Akt (1:500; cat. no. ab8805; Abcam), rabbit anti-p-Akt antibody (1:2,000; cat. no. 4060; Cell Signaling Technology, Inc.), rabbit anti-mTOR (1:1,000; cat. no. ab137341; Abcam), rabbit anti-p-mTOR antibody (1:1,000; cat. no. 5536; Cell Signaling Technology, Inc.) and rabbit anti-GAPDH (1:1,000; cat. no. ab9485; Abcam) at $4^{\circ} \mathrm{C}$ overnight. Subsequently, membranes were washed with TBST and incubated with goat anti-rabbit horseradish peroxidase-conjugated antibodies (1:2,000; SA00001-2, ProteinTech Group, Inc., Chicago, IL, USA) at room temperature for $90 \mathrm{~min}$. The protein bands were visualized using an ECL system (Amersham; GE Healthcare, Chicago, IL, USA). Densitometric analysis of western blots was performed using Quantity One ${ }^{\circledR}$ software version 2.4 (Bio-Rad, Laboratories, Inc., Hercules, CA, USA).

Cell Counting Kit-8 (CCK-8) cell viability analysis. Cells were dissociated using $0.25 \%$ trypsin, $0,12,24$ and $48 \mathrm{~h}$ after transfection. Then, cells were seeded in 96-well plates at a density of $1 \times 10^{4}$ cells/well and $10 \mu \mathrm{l}$ CCK- 8 solution was added to the cells for $2 \mathrm{~h}$ at $37^{\circ} \mathrm{C}$. The optical density was measured at a wavelength of $450 \mathrm{~nm}$ using a microplate reader (Bio-Rad, Laboratories, Inc.). 
Table I. Primers used for reverse transcription-quantitative polymerase chain reaction.

\begin{tabular}{|c|c|c|}
\hline Gene & Primer & Sequence \\
\hline \multirow[t]{2}{*}{ CFHR3 } & Forward & 5'-TGGGCATTAGTCAAGAATACAGTAAAA-3' \\
\hline & Reverse & 5'-ATTAATGCCGCTTCAATATGACTTT-3' \\
\hline \multirow[t]{2}{*}{ Ki67 } & Forward & 5'-AAAGTGCCCAAGCCATAGA-3' \\
\hline & Reverse & 5'-CACCATTTGCCAGTTCCTC-3' \\
\hline \multirow[t]{2}{*}{ Survivin } & Forward & 5'-TCATCCTCACTGCGGCTGTC-3' \\
\hline & Reverse & 5'-AGGTCATCTCGGCTGTTCCTG-3' \\
\hline \multirow[t]{2}{*}{ Caspase-3 } & Forward & 5'-ACTGGACTGTGGCATTGAG-3' \\
\hline & Reverse & 5'-GAAACAATACATGGAATCTG-3' \\
\hline \multirow[t]{2}{*}{ Bax } & Forward & 5'-GCGAATTGGAGATGAACT-3' \\
\hline & Reverse & 5'-GTGAGCGAGGCGGTGAGGAC-3' \\
\hline \multirow[t]{2}{*}{ Bcl-2 } & Forward & 5'-GGTTGCCTTATGTATTTGTTTG-3' \\
\hline & Reverse & 5'-CCTCCGCAATGCTGAAAG-3' \\
\hline \multirow[t]{2}{*}{ PI3K } & Forward & 5'-ATGCCTGCTCTGTAGTGGTGG-3' \\
\hline & Reverse & 5'-CATTGAGGGAGTCGTTGTGC-3' \\
\hline \multirow[t]{2}{*}{ Akt } & Forward & 5'-TTGTCATGGAGTACGCCAACG-3' \\
\hline & Reverse & 5'-ACAGCCCGAAGTCTGTGATCTT-3' \\
\hline \multirow[t]{2}{*}{ mTOR } & Forward & 5'-CCAATCATTCGCATTCAGTCC-3' \\
\hline & Reverse & 5'-AACAAACTCATGTCCGTTGCTG-3' \\
\hline \multirow[t]{2}{*}{ GAPDH } & Forward & 5'-AATCTCATCACCATATTCCA-3' \\
\hline & Reverse & 5'-CCTGCTTCACCACCTTGTTG-3' \\
\hline
\end{tabular}

Akt, protein kinase B; Bax, Bcl-2-associated X; Bcl-2, B cell lymphoma 2; CFHR3, complement factor H-related 3; mTOR, mammalian target of rapamycin; PI3K, phosphoinositide 3-kinase.

Flow cytometry. Cells were harvested $48 \mathrm{~h}$ after transfection, and then digested by $0.25 \%$ trypsin without EDTA and collected in $1.5 \mathrm{ml}$ Eppendorf tubes. Cells were washed twice using washing buffer, and then incubated with Annexin V-FITC and propidium iodide (cat. no. 40302ES20; Yeasen, Shanghai, China) in the dark at $25^{\circ} \mathrm{C}$ for $20 \mathrm{~min}$. Binding buffer was added to each tube and apoptosis analyzed within $1 \mathrm{~h}$. The apoptosis rate is derived from the addition of right upper quadrant and right lower quadrant together.

Cell proliferation was measured using carboxyfluorescein succinimidyl ester (CFSE) (29). Cells were labeled with CellTrace ${ }^{\mathrm{TM}}$ CFSE kit (C34554; Invitrogen; Thermo Fisher Scientific, Inc.) for $10 \mathrm{~min}$ at $37^{\circ} \mathrm{C}$ and then washed twice with phosphate-buffered saline. The cells were incubated for at $\geq 10$ min before analysis to allow the CellTrace ${ }^{\mathrm{TM}}$ reagent to undergo acetate hydrolysis. Fluorescence was measured using a flow cytometer and Flow Jo version 10.0 software (FlowJo LLC, Ashland, OR, USA).

Statistical analysis. GraphPad Prism software version 6.0 (GraphPad Software, Inc., La Jolla, CA, USA) was used to perform statistical analyses. All data are presented as the mean \pm standard deviation. One-way analysis of variance followed by Tukey's post hoc test was used to compare the means of multiple groups. Correlation between CFHR3 expression levels and tumor diameter was analyzed by Pearson's correlation coefficient. $\mathrm{P}<0.05$ was considered to indicate a statistically significant difference.

\section{Results}

CFHR3 mRNA and protein expression levels in HCC and adjacent tissue. Survival analysis of patients with HCC from the TCGA database is shown in Fig. 1A. The overall survival of patients with $\mathrm{HCC}$ was significantly improved in the CFHR3 high expression group compared with the low expression group $\left(\mathrm{P}=9.62 \times 10^{-5}\right)$. CFHR3 expression levels in 27 different normal tissues were also compared (Fig. 1B) using the HPA RNA-seq normal tissues from NCBI (https://www.ncbi.nlm.nih.gov/ gene/10878). The data demonstrated that CFHR3 was only highly expressed in liver tissues, suggesting that CFHR3 may be tissue-specific and related to the progression of liver cancer.

In the present study, 42 patients with $\mathrm{HCC}$ were recruited, and CFHR3 mRNA expression levels in HCC and adjacent tissues were detected by RT-qPCR. Western blot analysis of CFHR3 protein expression levels was performed on tissue samples from six patients. The results revealed that CFHR3 mRNA expression levels $\left(2^{-\Delta \Delta C T}\right)$ were lower in cancer tissue compared with in adjacent normal liver tissue $(\mathrm{P}<0.05$; Fig. $2 \mathrm{~A})$. This was consistent with the western blot results, which demonstrated that CFHR3 protein expression levels were significantly decreased in HCC tissue ( $\mathrm{P}<0.01$; Fig. $2 \mathrm{~B})$. However, the correlation between CFHR3 expression levels and tumor diameter in the $42 \mathrm{HCC}$ cases was not significant ( $\mathrm{P}>0.05$; Fig. 2C).

CFHR3 expression in HCC cells. Huh-7 cells were transfected with the NC plasmid, and the RT-qPCR and western blot results 
A
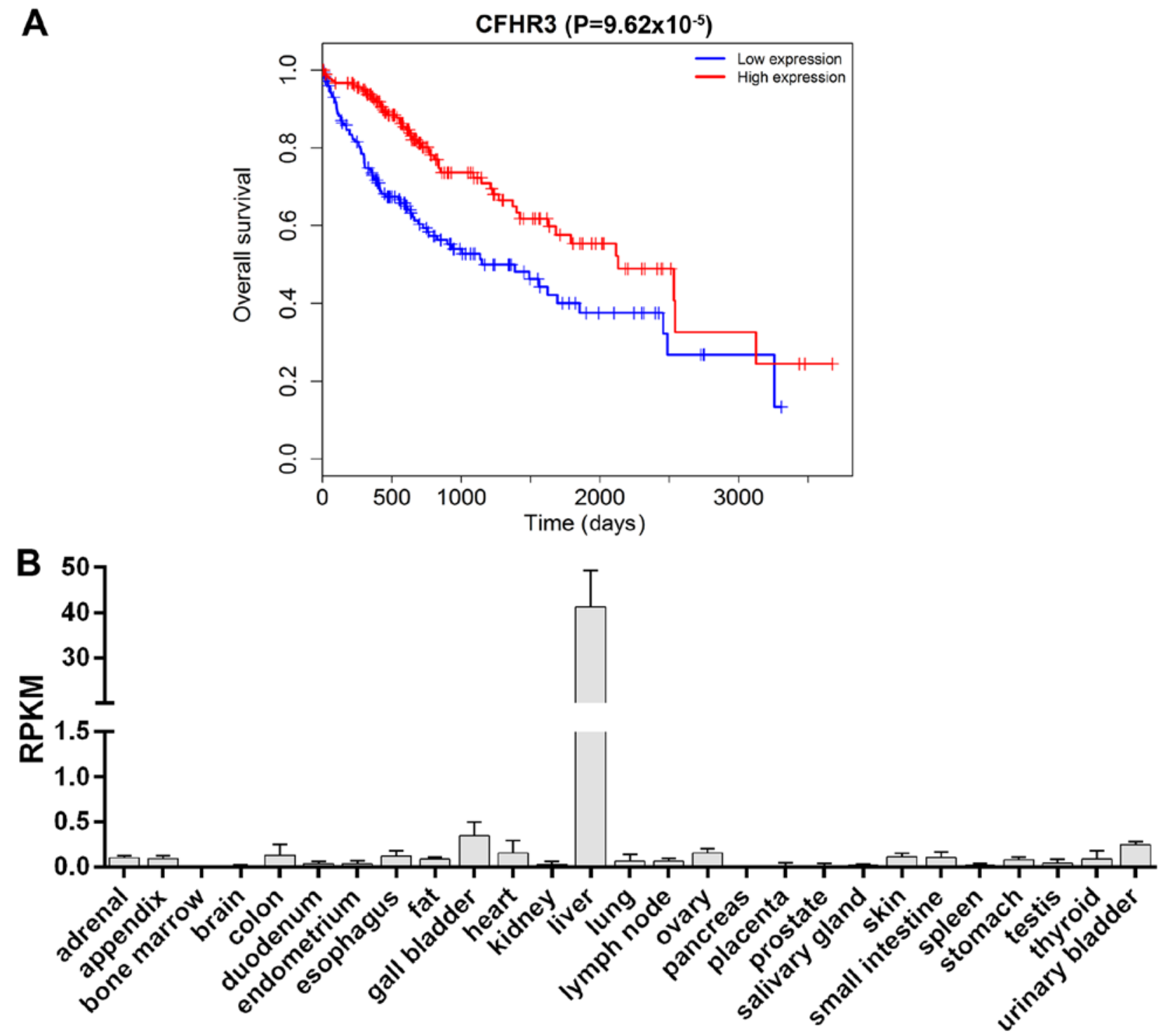

Figure 1. (A) Survival analysis in patients with hepatocellular carcinoma with high or low CFHR3 expression. The data was obtained from The Cancer Genome Atlas database. (B) CFHR3 expression levels in 27 different normal tissues. The data was obtained from the National Center for Biotechnology Information gene database. CFHR3, complement factor H-related 3; RPKM, reads per kilobase million.

demonstrated that transfection had no effect on CFHR3 expression levels compared with the control group. Cells transfected with the CFHR3 overexpression plasmid had significantly higher CFHR3 mRNA and protein expression levels compared with the control or NC group ( $\mathrm{P}<0.01$; Fig. $3 \mathrm{~A}$ and $\mathrm{B})$.

CFHR3 inhibits cell viability. Cell viability was detected using CCK-8 assay. The results revealed that at 24 and $48 \mathrm{~h}$ post-transfection cell viability was significantly decreased in the CFHR3 overexpression group compared with in the control or NC group $(\mathrm{P}<0.05$; Fig. $3 \mathrm{C})$. Therefore, the results suggested that cell viability can be inhibited by CFHR3.

Effect of CFHR3 on cell proliferation and apoptosis. Cell proliferation and apoptosis were measured using flow cytometry. CFHR3 overexpression significantly decreased the cell fluorescence intensity (M1 value; $\mathrm{P}<0.01$; Fig. 4A-D), indicating that CFHR3 inhibited cell proliferation. In addition, the results also demonstrated that CFHR3 overexpression significantly increased the apoptosis rate compared with the control or NC group $(\mathrm{P}<0.01$; Fig. 4E-H).

CFHR3 regulates the expression of proliferation- and apoptosis-related genes. In order to confirm the effects of CFHR3 on cell proliferation and apoptosis, protein and mRNA expression levels of proliferation- and apoptosis-related proteins and genes were detected using western blotting and RT-qPCR, respectively. The western blot results revealed that the protein expression levels of $\mathrm{Ki} 67$, survivin and Bcl-2 were significantly downregulated in the CFHR3 overexpression group $(\mathrm{P}<0.05$; Fig. 5A and $\mathrm{B})$. However, protein expression levels of active-caspase- 3 and Bax were significantly increased in the CFHR3 group compared with in the control or NC group $(\mathrm{P}<0.01$; Fig. 5A and B). A similar pattern was observed for mRNA expression levels. CFHR3 overexpression significantly decreased the mRNA expression levels of Ki67, survivin and Bcl-2 ( $\mathrm{P}<0.05$; Fig. 5C), whereas active-caspase-3 and Bax were significantly increased $(\mathrm{P}<0.05$; Fig. $5 \mathrm{C})$. 

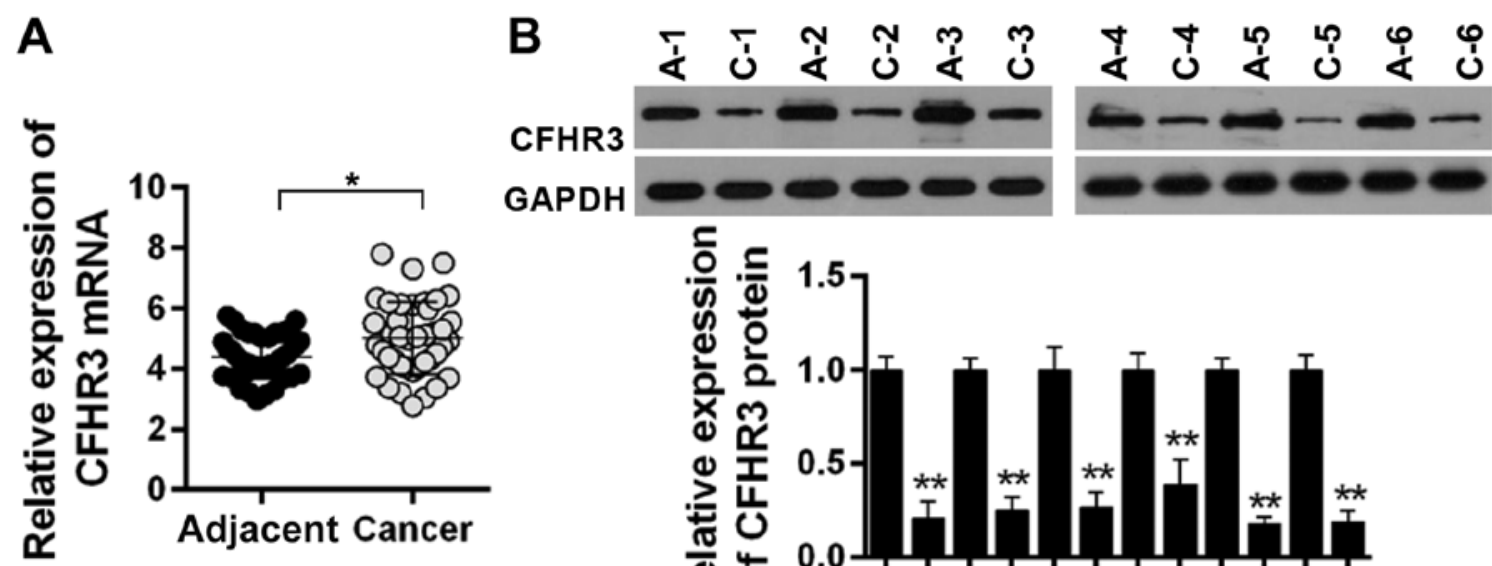

GAPDH
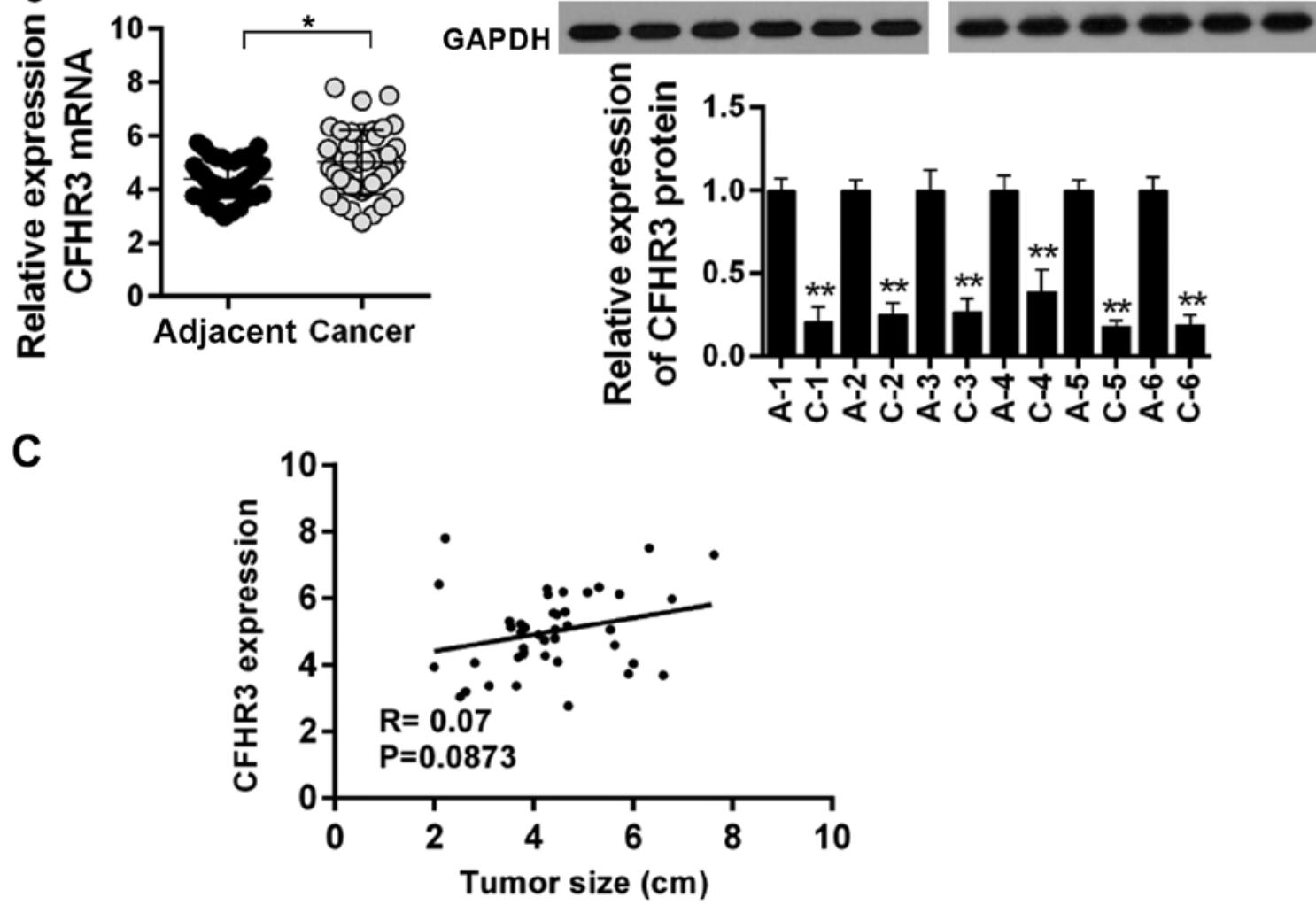

Figure 2. CFHR3 expression levels in HCC and adjacent tissue. (A) A total of 42 patients with HCC were recruited and relative CFHR3 mRNA expression levels were detected in HCC and adjacent tissue using reverse transcription-quantitative polymerase chain reaction. ${ }^{*} \mathrm{P}<0.05$. (B) CFHR3 protein expression levels were evaluated in the HCC and adjacent tissue of six patients with HCC by western blot analysis. (C) Correlation between CFHR 3 expression levels and tumor diameter in $42 \mathrm{HCC}$ cases. Data are presented as the mean \pm standard deviation from three independent experiments. ${ }^{* *} \mathrm{P}<0.01 \mathrm{vs}$. Adjacent. A, adjacent; C, cancer; CFHR3; complement factor H-related 3; HCC, hepatocellular carcinoma.
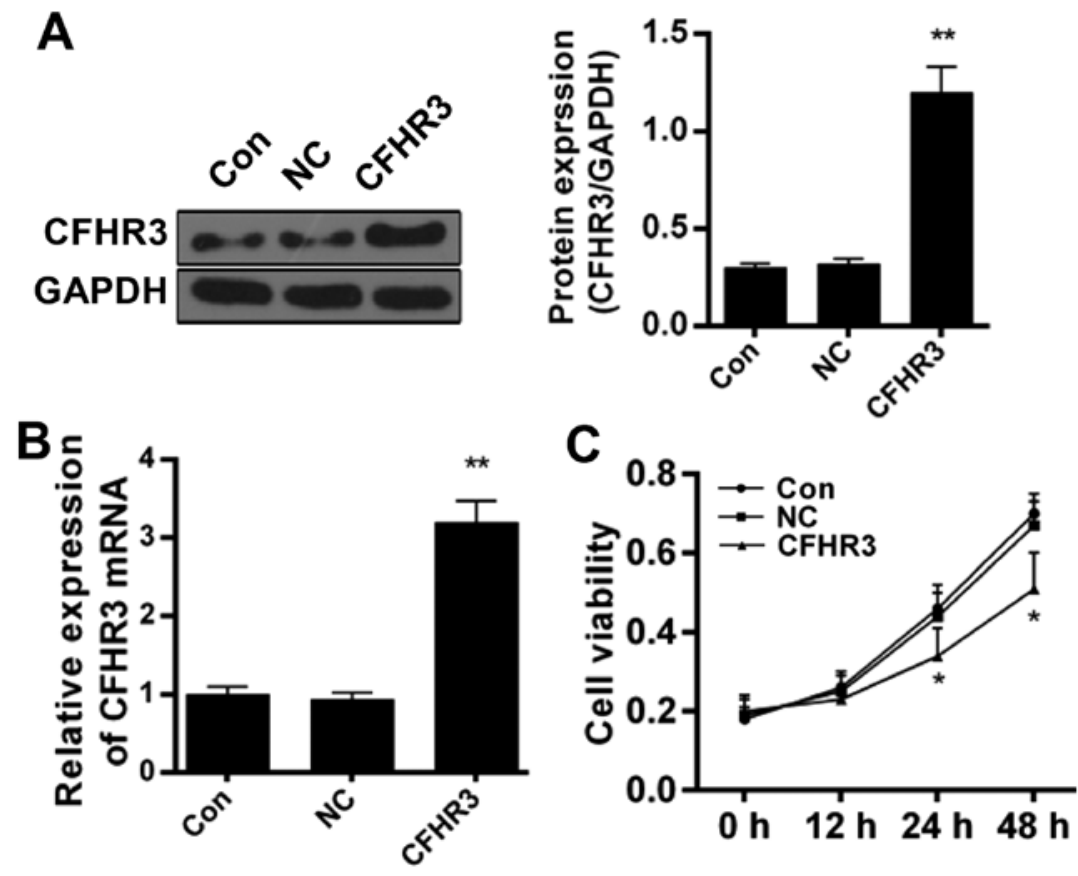

Figure 3. Effect of CFHR3 on the cell viability of Huh-7 cells. Huh-7 cells were transfected with the CFHR3 overexpression plasmid and transfection efficiency was confirmed by (A) western blot analysis and (B) reverse transcription-quantitative polymerase chain reaction. (C) Cell viability was determined using the cell counting kit-8 assay. Data are presented as the mean \pm standard deviation from three independent experiments. ${ }^{*} \mathrm{P}<0.05,{ }^{* * *} \mathrm{P}<0.01 \mathrm{vs}$. Con. CFHR3, complement factor H-related 3; Con, control; NC, negative control. 

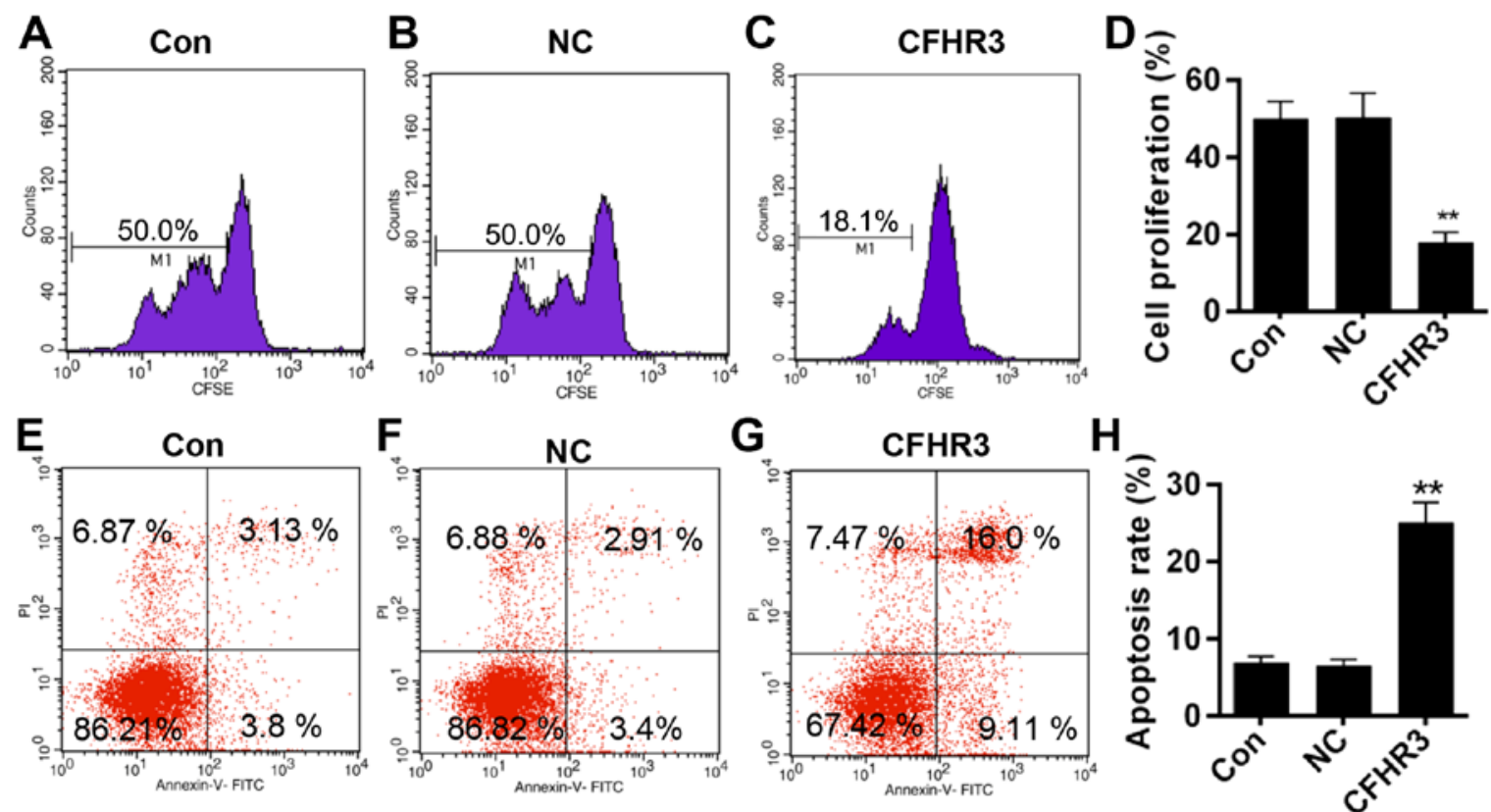

Figure 4. Effect of CFHR3 on Huh-7 cell proliferation and apoptosis. (A-C) Cell proliferation was measured by flow cytometric analysis of CFSE. (D) Quantification of the cell proliferation data. (E-G) Apoptosis was detected by flow cytometric analysis of Annexin V-FITC- and PI-stained cells. (H) Quantification of the apoptosis rate. Data are presented as the mean \pm standard deviation from three independent experiments. ${ }^{* *} \mathrm{P}<0.01$ vs. Con. Con, control; NC, negative control; CFHR3, complement factor H-related 3; CFSE, carboxyfluorescein succinimidyl ester; FITC, fluorescein isothiocyanate; PI, propidium iodide.

A

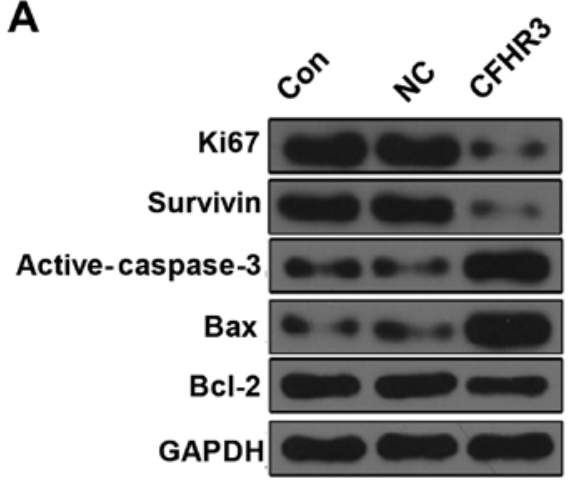

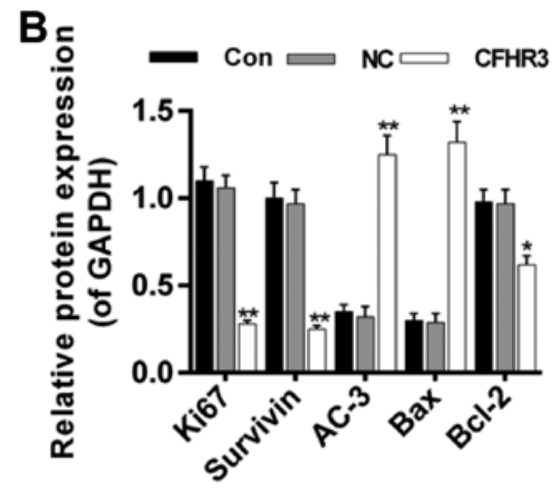

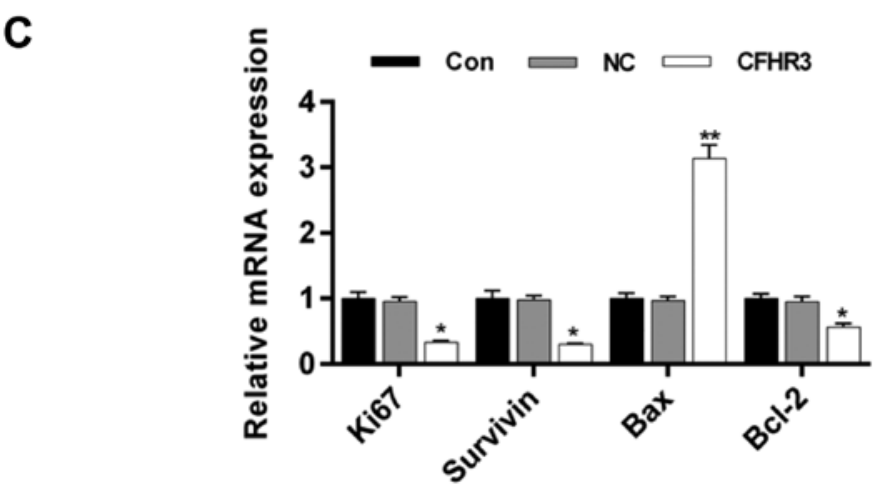

Figure 5. Effect of CFHR3 on the expression of proliferation- and apoptosis-related genes and proteins in Huh-7 cells. (A) Western blotting was performed to determine the protein expression levels of Ki67, survivin, active-caspase-3, Bax and Bcl-2. (B) Summary of the relative protein expression levels. (C) Reverse transcription-quantitative polymerase chain reaction was performed to determine the mRNA expression levels of Ki67, survivin, Bax and Bcl-2. Expression levels were normalized to GAPDH. Data are presented as the mean \pm standard deviation from three independent experiments. ${ }^{*} \mathrm{P}<0.05,{ }^{* *} \mathrm{P}<0.01$ vs. Con. AC-3, active-caspase-3; Bax, Bcl-2-associated X; Bcl-2, B cell lymphoma 2; CFHR3, complement factor H-related 3; Con, control; NC, negative control.

CFHR3 inhibits PI3K/Akt/mTOR signaling. The protein expression levels of PI3K, Akt and mTOR were detected in order to determine the potential involvement of the PI3K/Akt/ mTOR signaling pathway in HCC. The results demonstrated 

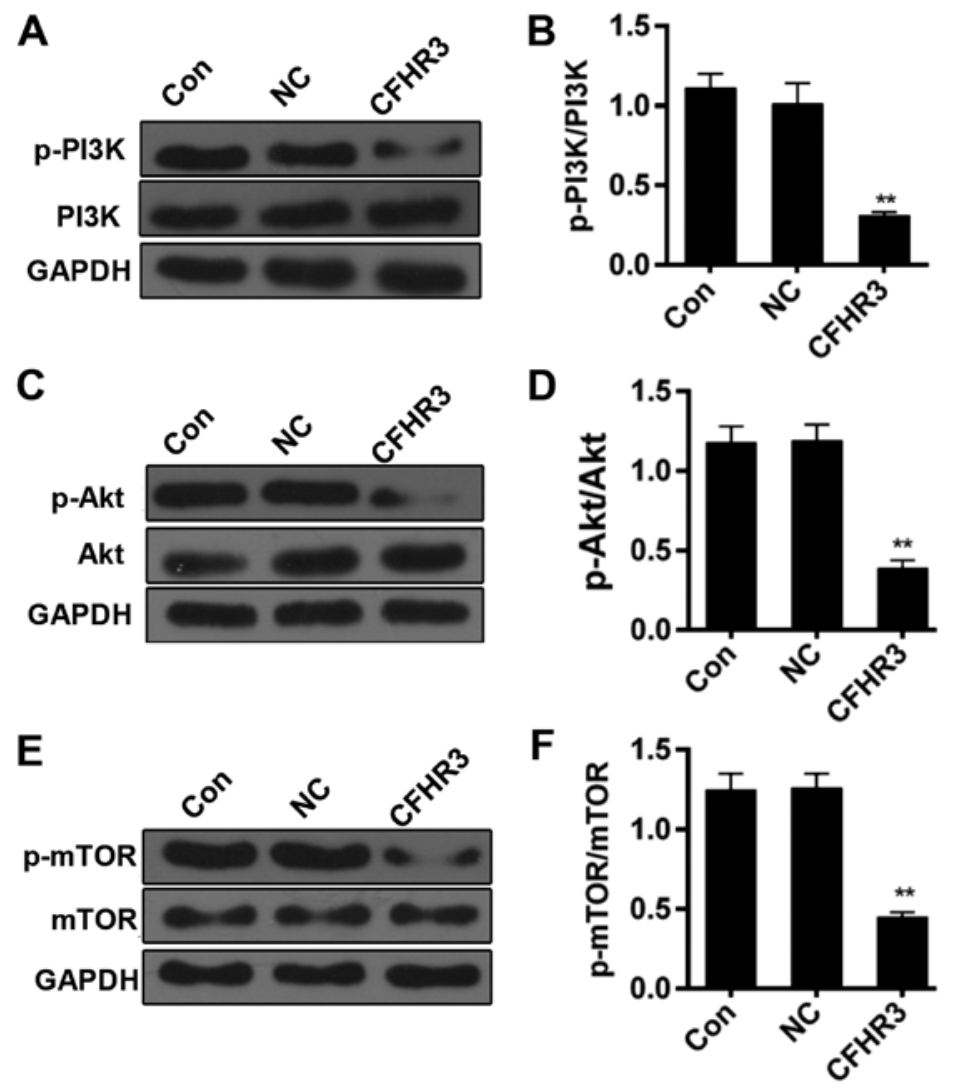

Figure 6. Effect of CFHR3 on the PI3K/Akt/mTOR signaling pathway in Huh-7 cells. Western blotting was used to determine the protein expression levels of (A and B) p-PI3K, (C and D) p-Akt and (E and F) p-mTOR. Data are presented as the mean \pm standard deviation from three independent experiments. ${ }^{* *} \mathrm{P}<0.01$ vs. Con. Akt, protein kinase B; Con, control; mTOR, mammalian target of rapamycin; NC, negative control; p, phosphorylated; PI3K, phosphoinositide 3-kinase.

no noticeable differences in the protein expression levels of PI3K, Akt and mTOR among the control, NC and CFHR3 groups. However, CFHR3 significantly inhibited the phosphorylation of PI3K, Akt and mTOR (P<0.01; Fig. 6). Taken together, the results suggested that CFHR3 can inhibit liver cancer cell growth via the PI3K/Akt/mTOR pathway.

\section{Discussion}

CFHR3 is mainly studied in the context of IgA nephropathy, age-related macular degeneration and atypical hemolytic uremic syndrome (30-32). Previous studies have demonstrated that CFH family proteins may be important in cancer $(19,20,33)$; however, little is known about the role of CFHR3 in cancer. Researchers have suggested that high expression levels of CFHR 3 could increase the risk of neuroblastoma and glioma $(19,34)$. CFHR 3 is tissue-specific and is related to the progression of liver cancer. In the present study, the expression of CFHR 3 in different normal human tissues was investigated and it was demonstrated that CFHR3 was highly expressed in normal liver tissues. In addition, high expression of CFHR3 in patients with HCC resulted in an improvement in overall survival. Therefore, it was hypothesized that CFHR3 may inhibit the occurrence and development of HCC. To further validate this, 42 patients with $\mathrm{HCC}$ were recruited, and expression of CFHR 3 in HCC and adjacent normal tissues were detected. The results demonstrated that liver cancer tissue had a lower CFHR3 mRNA $\left(2^{-\Delta \Delta C q}\right)$ and protein levels compared with normal tissue. However, no significant correlation between CFHR3 expression level and tumor diameter was identified in the 42 HCC cases. The sample size in this study was relatively small, which may affect the results obtained.

Liver cancer is one of the most common forms of cancer. Surgical resection and chemotherapy are the most common strategies to treat HCC (35-38). However, the prognosis for patients with liver cancer has not been improved significantly. Thus, it is necessary to develop new approaches to treat liver cancer. In the present study, CFHR3 was overexpressed in HCC cells. This resulted in a significant inhibition of cell viability and proliferation, whereas apoptosis was significantly upregulated. The protein and mRNA expression levels of proliferation- and apoptosis-related genes were also detected. The results suggested that CFHR3 inhibited proliferation and induced apoptosis by downregulating the expression of Ki67, Bcl-2 and survivin, and upregulating the expression of Bax and active-caspase-3. Ki67 is a cell proliferation marker (39). Survivin is an important member of the inhibitor of apoptosis protein family and serves a critical role in the inhibition of apoptosis $(40,41)$. Caspase-3 is a key protein of the caspase family and has a major role in the execution-phase of apoptosis (42).

The occurrence and development of primary liver cancer is closely related to cell signaling pathways. The signal transduction pathways in HCC form a complex network, which involves multi-factor and multi-protein pathways. Cell growth is associated with several major molecular pathways, including Ras/ 
mitogen-activated protein kinase kinase, PI3K/Akt/mTOR, Wnt $/ \beta$-catenin, Janus kinase/signal transducer and activator of transcription (43-47). Among these four pathways, the PI3K/ $\mathrm{Akt} / \mathrm{mTOR}$ pathway is most closely related to HCC (48). PI3K is a heterodimer that is composed of a regulatory $\mathrm{p} 85$ subunit and a catalytic p110 subunit. PI3K is found in the cytoplasm, and when activated, aggregates to the cell membrane and interacts with the pleckstrin homology domain of Akt, leading to its activation. mTOR is a downstream molecule of the PI3K/ Akt pathway, which controls cell growth and proliferation by regulating the cell cycle. Dysregulation of the cell cycle can lead to cell transformation and tumor deterioration $(49,50)$. In the present study, the results revealed that CFHR3 significantly inhibited the phosphorylation and thereby inactivation of PI3K, Akt and mTOR.

However, only the effects of CFHR3 overexpression were demonstrated in the present study. Therefore, using a knock-down of CFHR3 could strengthen the results. In addition, the TCGA database contains an abundant of clinical information. It would be useful to conduct multivariate Cox regression analysis to identify the effect of other important prognostic factors, including serum $\alpha$-fetoprotein, tumor stage, cirrhosis, vascular tumors and inflammation on overall survival rates, using blood samples. This analysis would help evaluate the independent prognostic value of CFHR3 mRNA expression. In addition, an association between CFHR3 expression and tumor diameter could further confirm the results obtained from the in vitro experiments. Future experiments in vivo will also aid in validating the results and investigations probing into the definite mechanism underlying the effect of CFHR3 will be of interest.

In conclusion, the results from the present study suggested that CFHR3 functions as a tumor suppressor. CFHR3 may suppress proliferation and promote apoptosis via the PI3K/ Akt/mTOR signaling pathway.

\section{Acknowledgements}

Not applicable.

\section{Funding}

No funding was received.

\section{Availability of data and materials}

The datasets used and/or analyzed during the present study are available from the corresponding author on reasonable request.

\section{Authors' contributions}

HL made substantial contributions to the conception and design of the present study. LZ and PW performed data acquisition, analysis and interpretation. PW and HL drafted the article and critically revised it for important intellectual content. All authors approved the final version of the published article. LZ agreed to be accountable for all aspects of the work in ensuring that questions related to the accuracy or integrity of the study are appropriately investigated and resolved.

\section{Ethics approval and consent to participate}

The present study was approved by the Ethics Committee of Yantai Infectious Disease Hospital (Yantai, China). Written informed consent was obtained from patients.

\section{Patient consent for publication}

Written informed consent was obtained from patients.

\section{Competing interests}

The authors declare that they have no competing interests.

\section{References}

1. Torre LA, Bray F, Siegel RL, Ferlay J, Lortet-Tieulent J and Jemal A: Global cancer statistics, 2012. CA Cancer J Clin 65: 87-108, 2015.

2. European Association For The Study Of The Liver; European Organisation For Research And Treatment Of Cancer: EASL-EORTC clinical practice guidelines: Management of hepatocellular carcinoma. J Hepatol 56: 908-943, 2012.

3. Chan SL, Wong AM, Lee K, Wong N and Chan AK: Personalized therapy for hepatocellular carcinoma: Where are we now? Cancer Treat Rev 45: 77-86, 2016.

4. Liu J and Fan D: Hepatitis B in China. Lancet 369: 1582-1583, 2007.

5. Mohd Hanafiah K, Groeger J, Flaxman AD and Wiersma ST: Global epidemiology of hepatitis $C$ virus infection: New estimates of age-specific antibody to HCV seroprevalence. Hepatology 57: 1333-1342, 2013.

6. Sartorius K, Sartorius B, Aldous C, Govender PS and Madiba TE: Global and country underestimation of hepatocellular carcinoma (HCC) in 2012 and its implications. Cancer Epidemiol 39: 284-290, 2015.

7. Fagerberg L, Hallstrom BM, Oksvold P, Kampf C, Djureinovic D, Odeberg J, Habuka M, Tahmasebpoor S, Danielsson A, Edlund $\mathrm{K}$, et al: Analysis of the human tissue-specific expression by genome-wide integration of transcriptomics and antibody-based proteomics. Mol Cell Proteomics 13: 397-406, 2014.

8. Zipfel PF, Skerka C, Hellwage J, Jokiranta ST, Meri S, Brade V, Kraiczy P, Noris M and Remuzzi G: Factor H family proteins: On complement, microbes and human diseases. Biochem Soc Trans 30: 971-978, 2002.

9. Hellwage J, Jokiranta TS, Koistinen V, Vaarala O, Meri S and Zipfel PF: Functional properties of complement factor H-related proteins FHR-3 and FHR-4: Binding to the $\mathrm{C} 3 \mathrm{~d}$ region of $\mathrm{C} 3 \mathrm{~b}$ and differential regulation by heparin. FEBS Lett 462: 345-352, 1999.

10. McRae JL, Duthy TG, Griggs KM, Ormsby RJ, Cowan PJ, Cromer BA, McKinstry WJ, Parker MW, Murphy BF and Gordon DL: Human factor H-related protein 5 has cofactor activity, inhibits C 3 convertase activity, binds heparin and C-reactive protein, and associates with lipoprotein. J Immunol 174: 6250-6256, 2005.

11. Kotarsky H, Hellwage J, Johnsson E, Skerka C, Svensson HG, Lindahl G, Sjobring U and Zipfel PF: Identification of a domain in human factor $\mathrm{H}$ and factor $\mathrm{H}$-like protein-1 required for the interaction with streptococcal M proteins. J Immunol 160: 3349-3354, 1998.

12. Appel GB, Cook HT, Hageman G, Jennette JC, Kashgarian M, Kirschfink M, Lambris JD, Lanning L, Lutz HU, Meri S, et al: Membranoproliferative glomerulonephritis type II (dense deposit disease): An update. J Am Soc Nephrol 16: 1392-1403, 2005.

13. Venables JP, Strain L, Routledge D, Bourn D, Powell HM, Warwicker P, Diaz-Torres ML, Sampson A, Mead P, Webb M, et al: Atypical haemolytic uraemic syndrome associated with a hybrid complement gene. PLoS Med 3: e431, 2006.

14. Zipfel PF, Edey M, Heinen S, Jozsi M, Richter H, Misselwitz J, Hoppe B, Routledge D, Strain L, Hughes AE, et al: Deletion of complement factor H-related genes CFHR1 and CFHR3 is associated with atypical hemolytic uremic syndrome. PLoS Genet 3: e41, 2007.

15. Monteferrante G, Brioschi S, Caprioli J, Pianetti G, Bettinaglio P, Bresin E, Remuzzi G and Noris M: Genetic analysis of the complement factor $\mathrm{H}$ related 5 gene in haemolytic uraemic syndrome. Mol Immunol 44: 1704-1708, 2007. 
16. Hughes AE, Orr N, Esfandiary H, Diaz-Torres M, Goodship T and Chakravarthy U: A common CFH haplotype, with deletion of CFHR1 and CFHR3, is associated with lower risk of age-related macular degeneration. Nat Genet 38: 1173-1177, 2006.

17. Hageman GS, Hancox LS, Taiber AJ, Gehrs KM, Anderson DH, Johnson LV, Radeke MJ, Kavanagh D, Richards A, Atkinson J, et al Extended haplotypes in the complement factor $\mathrm{H}(\mathrm{CFH})$ and $\mathrm{CFH}-$ related (CFHR) family of genes protect against age-related macular degeneration: Characterization, ethnic distribution and evolutionary implications. Ann Med 38: 592-604, 2006.

18. Kavanagh D, Richards A and Atkinson J: Complement regulatory genes and hemolytic uremic syndromes. Annu Rev Med 59: 293-309, 2008

19. Kinders R, Jones T, Root R, Bruce C, Murchison H, Corey M, Williams L, Enfield D and Hass GM: Complement factor H or a related protein is a marker for transitional cell cancer of the bladder. Clin Cancer Res 4: 2511-2520, 1998.

20. Junnikkala S, Jokiranta TS, Friese MA, Jarva H, Zipfel PF and Meri S: Exceptional resistance of human $\mathrm{H} 2$ glioblastoma cells to complement-mediated killing by expression and utilization of factor $\mathrm{H}$ and factor H-like protein 1. J Immunol 164: 6075-6081, 2000.

21. Corey MJ, Kinders RJ, Poduje CM, Bruce CL, Rowley H, Brown LG, Hass GM and Vessella RL: Mechanistic studies of the effects of anti-factor $\mathrm{H}$ antibodies on complement-mediated lysis. J Biol Chem 275: 12917-12925, 2000.

22. Fedarko NS, Fohr B, Robey PG, Young MF and Fisher LW: Factor $\mathrm{H}$ binding to bone sialoprotein and osteopontin enables tumor cell evasion of complement-mediated attack. J Biol Chem 275 : $16666-16672,2000$

23. Jozsi M, Manuelian T, Heinen S, Oppermann M and Zipfel PF: Attachment of the soluble complement regulator factor $\mathrm{H}$ to cell and tissue surfaces: Relevance for pathology. Histol Histopathol 19: 251-258, 2004

24. Fedarko NS, Jain A, Karadag A, Van Eman MR and Fisher LW: Elevated serum bone sialoprotein and osteopontin in colon, breast, prostate, and lung cancer. Clin Cancer Res 7: 4060-4066, 2001.

25. Cui L, Fu J, Pang JC, Qiu ZK, Liu XM, Chen FR, Shi HL, Ng HK and Chen ZP: Overexpression of IL-7 enhances cisplatin resistance in glioma. Cancer Biol Ther 13: 496-503, 2012.

26. Sabatini DM: mTOR and cancer: Insights into a complex relationship. Nat Rev Cancer 6: 729-734, 2006.

27. Ayuso C, Rimola J, Vilana R, Burrel M, Darnell A, García-Criado A, Bianchi L, Belmonte E, Caparroz C, Barrufet M, Bruix J, Brú C: Diagnosis and staging of hepatocellular carcinoma (HCC): current guidelines. Eur J Radiol 101:72-81,2018.

28. Livak KJ and Schmittgen TD: Analysis of relative gene expression data using real-time quantitative PCR and the 2(-Delta Delta C(T)) method. Methods 25: 402-408, 2001.

29. Hoefel D, Grooby WL, Monis PT, Andrews S and Saint CP: A comparative study of carboxyfluorescein diacetate and carboxyfluorescein diacetate succinimidyl ester as indicators of bacterial activity. J Microbiol Methods 52: 379-388, 2003.

30. Gharavi AG, Kiryluk K, Choi M, Li Y, Hou P, Xie J, Sanna-Cherchi S, Men CJ, Julian BA, Wyatt RJ, et al: Genome-wide association study identifies susceptibility loci for IgA nephropathy. Nat Genet 43: 321-327, 2011.

31. Munch J, Bachmann A, Grohmann M, Mayer C, Kirschfink M, Lindner TH, Bergmann C and Halbritter J: Effective immunosuppressive management with belatacept and eculizumab in post-transplant aHUS due to a homozygous deletion of CFHR1/CFHR3 and the presence of CFH antibodies. Clin Kidney J 10: 742-746, 2017.

32. Bakri NM, Ramachandran V, Kee HF, Subrayan V, Isa H Ngah NF, Mohamad NA, Mooi CS, Mun CY, Ismail P, et al: Association of copy number variations in complement factor $\mathrm{H}$-Related genes among age-related macular degenerative subjects. Kaohsiung J Med Sci 33: 602-608, 2017.

33. Junnikkala S, Hakulinen J, Jarva H, Manuelian T, Bjorge L, Butzow R, Zipfel PF and Meri S: Secretion of soluble complement inhibitors factor $\mathrm{H}$ and factor $\mathrm{H}-$ like protein (FHL-1) by ovarian tumour cells. Br J Cancer 87: 1119-1127, 2002.
34. Khan FH, Pandian V, Ramraj S, Natarajan M, Aravindan S, Herman TS and Aravindan N: Acquired genetic alterations in tumor cells dictate the development of high-risk neuroblastoma and clinical outcomes. BMC Cancer 15: 514, 2015.

35. Hanazaki K, Kajikawa S, Shimozawa N, Mihara M, Shimada K, Hiraguri M, Koide N, Adachi W and Amano J: Survival and recurrence after hepatic resection of 386 consecutive patients with hepatocellular carcinoma. J Am Coll Surg 191: 381-388, 2000.

36. Poon RT, Fan ST, Lo CM, Ng IO, Liu CL, Lam CM and Wong J: Improving survival results after resection of hepatocellular carcinoma: A prospective study of 377 patients over 10 years. Ann Surg 234: 63-70, 2001

37. Bosch $\mathbf{J}$ and Forns X: Therapy. Statins and liver disease: From concern to 'wonder' drugs? Nat Rev Gastroenterol Hepatol 12: 320-321, 2015.

38. Zhang H, Gao C, Fang L, Zhao HC and Yao SK: Metformin and reduced risk of hepatocellular carcinoma in diabetic patients: A meta-analysis. Scand J Gastroenterol 48: 78-87, 2013.

39. Forones NM, Carvalho AP, Giannotti-Filho O, Lourenço LG and Oshima CT: Cell proliferation and apoptosis in gastric cancer and intestinal metaplasia. Arq Gastroenterol 42: 30-44, 2005.

40. Ambrosini G, Adida C and Altieri DC: A novel anti-apoptosis gene, survivin, expressed in cancer and lymphoma. Nat Med 3: 917-921, 1997.

41. Altieri DC: Survivin, cancer networks and pathway-directed drug discovery. Nat Rev Cancer 8: 61-70, 2008.

42. Choudhary GS, Al-Harbi S and Almasan A: Caspase-3 activation is a critical determinant of genotoxic stress-induced apoptosis. Methods Mol Biol 1219: 1-9, 2015.

43. Newell P, Toffanin S, Villanueva A, Chiang DY, Minguez B, Cabellos L, Savic R, Hoshida Y, Lim KH, Melgar-Lesmes P, et al: Ras pathway activation in hepatocellular carcinoma and anti-tumoral effect of combined sorafenib and rapamycin in vivo. J Hepatol 51: 725-733, 2009.

44. Villanueva A, Toffanin S and Llovet JM: Linking molecular classification of hepatocellular carcinoma and personalized medicine: Preliminary steps. Curr Opin Oncol 20: 444-453, 2008.

45. Wang J, Ouyang C, Chen X, Fu B, Lu Y and Hong Q: Effect of Jak2 kinase inhibition on Stat 1 and Stat 3 activation and apoptosis of tubular epithelial cells induced by ATP depletion/recovery. J Nephrol 21: 919-923, 2008

46. Quentmeier H, Geffers R, Jost E, Macleod RA, Nagel S, Rohrs S, Romani J, Scherr M, Zaborski M and Drexler HG: SOCS2: Inhibitor of JAK2V617F-mediated signal transduction. Leukemia 22: 2169-2175, 2008.

47. Herbst A and Kolligs FT: Wnt signaling as a therapeutic target for cancer. Methods Mol Biol 361: 63-91, 2007.

48. Yang J, Pi C and Wang G: Inhibition of PI3K/Akt/mTOR pathway by apigenin induces apoptosis and autophagy in hepatocellular carcinoma cells. Biomed Pharmacother 103: 699-707, 2018.

49. Zhao L, Li C, Liu F, Zhao Y, Liu J, Hua Y, Liu J, Huang J and Ge C: A blockade of PD-L1 produced antitumor and antimetastatic effects in an orthotopic mouse pancreatic cancer model via the PI3K/Akt/mTOR signaling pathway. Onco Targets Ther 10: 2115-2126, 2017.

50. Wang X, Zeng J, Wang L, Zhang X, Liu Z, Zhang H and Dong J: Overexpression of microRNA-133b is associated with the increased survival of patients with hepatocellular carcinoma after curative hepatectomy: Involvement of the EGFR/PI3K/Akt/ mTOR signaling pathway. Oncol Rep 38: 141-150, 2017.

This work is licensed under a Creative Commons Attribution-NonCommercial-NoDerivatives 4.0 International (CC BY-NC-ND 4.0) License. 